\title{
IN MEMORIAM: JAMES L. ZARUCCHI (1952-2019)
}

When Jim Zarucchi took Biology 104 "Plants and Human Affairs" in 1972, his junior year at Harvard University, his planned career path changed. Switching from premedical studies to botany, he began working with the famous and charismatic professor Richard Evans Schultes. Numerous anecdotes from that class sparked in Jim an enthusiasm and a desire to travel to remote places, and by spring of 1973 , he was on his way to Colombia, where he teamed up with Doel Soejarto, professor at the Universidad de Antioquia in Medellín at the time. Jim celebrated his 21st birthday in the middle of the Colombian jungle on the first of many adventurous botanical expeditions he undertook there in the 1970s and 1980s. Following in Schultes' footsteps, Jim would often recall his travels to remote places in the Amazon with Colombian botanist Isidoro Cabrera. Jim was one of the organizers of the Flora de Antioquia project (R. Callejas, pers. comm.), even describing the apocynaceous genus Quiotania (an anagram for the department of Antioquia).

Born on May 26, 1952, as one of five siblings, Jim grew up and attended high school in Eureka, California, where many in his family still live. Following his bachelor's degree from Harvard, he remained there to complete both Master's and Ph.D. degrees. For his doctoral dissertation he studied the Apocynaceae, the dogbane family, finishing his work in 1981 under Schultes' guidance. Two postdoctoral positions followed, one in London at the British Museum and Kew Gardens, and one at the Smithsonian Institution, before he and his wife, Dr. Jeanne Morgan Zarucchi, whom he met at Harvard, moved to St. Louis.

Jim joined the Missouri Botanical Garden as an Assistant Curator in 1984, filling a position advertised for a legume specialist, and worked actively with legumes while coordinating studies on the family as well as scientific meetings. In 1990, he was promoted to Associate Curator and appointed as coeditor of the Catalogue of the Flowering Plants and Gymnosperms of Peru, published in 1993. That same year he began managing the Flora of China Checklist, an online inventory of the plants of China. Jim also served on the Directorate of the International Legume Database and Information Service (ILDIS). He was the primary botanical author of the two-volume Phytochemical Dictionary of the Leguminosae, which contains chemical occurrence data for nearly 2700 species of legumes worldwide, published in late 1994.

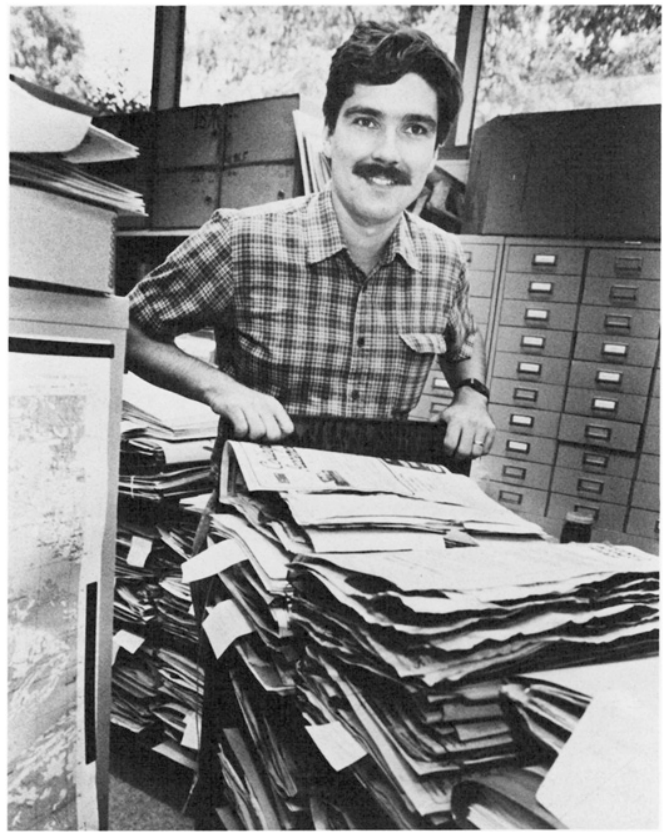

Jim joined the Flora of North America project in 1996 as Managing Editor and later Editorial Director, and from 2003 onward he was Vice President and Editorial Director. In 2000, the Flora of North America Association set up multiple editorial centers responsible for specific volumes, leaving Jim in charge of the editorial and organizational center in St. Louis. He saw 18 volumes through to publication and was heavily involved in all remaining volumes; he was a skillful and detail-oriented editor and did an excellent job advancing the project. In addition to his own work on developing the nomenclatural backbone, checking nomenclature and bibliography, Jim oversaw the work of dozens of people, even hundreds at a time, including illustrators, technical editors, and composition contractors-and acted much like "an orchestra conductor," as he told a reporter some years ago.

In 2006, Jim was named the Anne L. Lehmann Curator of North American Botany, an endowed position at the Garden, which he held for the rest of his life. Jim contributed accounts of various genera of Apocynaceae and Fabaceae families for multiple 


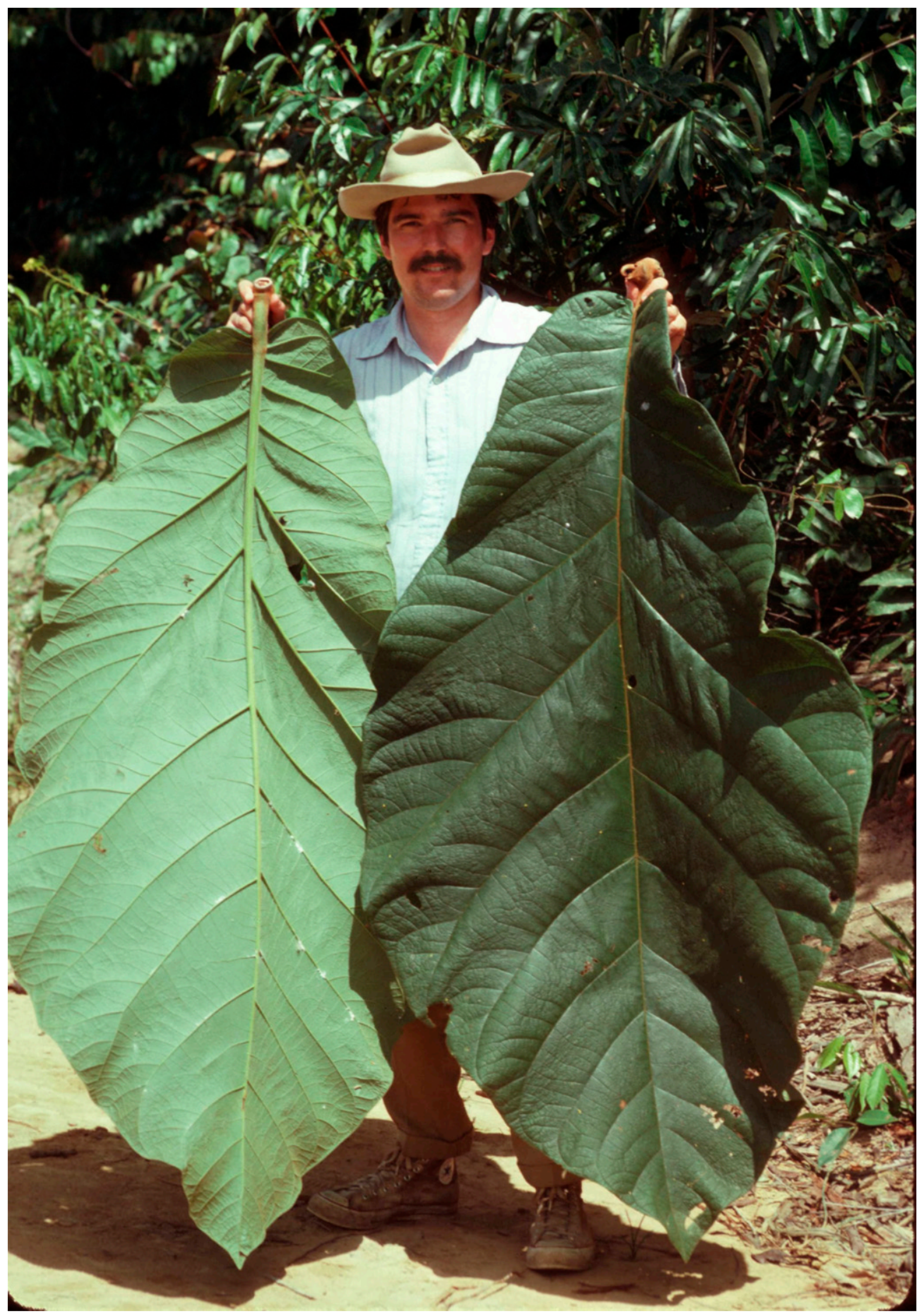

Jim Zarucchi holding two Coccoloba leaves near Borba, Amazonas, Brazil, in June 1983. @J. Zarucchi

Garden floristic projects (Flora Mesoamericana, Flora de Nicaragua, Flora of the Venezuelan Guayana, Catalogue of the Vascular Plants of Ecuador). He authored or coauthored some 100 papers and book chapters, most recently participating in the benchmark paper "An integrated assessment of the vascular plant species of the Americas" published in Science in 2017. 
The majority of Jim's 5720 plant collections came from remote sites in Colombia, but he also collected in Brazil, Madagascar, Ecuador, and the United States. He described 12 plant species new to science and made more than 60 combinations. Various colleagues honored him with a dozen plant species bearing his name. Jim had many friends at the Garden and he worked with an extensive network of botanists around the world. He belonged to various botanical societies worldwide. He was also a Faculty Associate at the University of Missouri-St. Louis and a Biodiversity Fellow at the Living Earth Collaborative of Washington University.

Jim was an avid gardener and enjoyed the company of his dog, Daisy Mae. He was thrilled to grow new varieties of fruits and vegetables and to share those with his colleagues at work.

We will remember Jim fondly!

—Carmen Ulloa Ulloa, Tammy Charron, and Jennifer Kuhl, Missouri Botanical Garden 